УДК 631.51:631.81:633.4

(C) 2018

Цвей Я. П., доктор сільськогосподарських наук

Інститут біоенергетичних культур і цукрових буряків НААН України

Тищенко М. В., кандидат сільськогосподарських наук,

Герасименко Ю. П., науковий співробітник

Веселоподільська дослідно-селекційна станція

Інституту біоенергетичних культур і цукрових буряків НААН України

Філоненко С. В., кандидат сільськогосподарських наук,

Ляшенко В. В., кандидат сільськогосподарських наук

Полтавська державна аграрна академія

\title{
ОБРОБІТОК ГРУНТУ, ДОБРИВА ТА ПРОДУКТИВНІСТЬ ЦУКРОВИХ БУРЯКІВ
}

\section{Рецензент - доктор сільськогосподарських наук, професор П. В. Писаренко}

У статті наводяться результати досліджень впливу систем основного обробітку трунту на продуктивність иукрових буряків за органічної та мінеральної системи їх удобрення в короткоротаційній плодозмінній сівозміні. Викладений деталізований аналіз особливостей формування врожаю коренеплодів та ïx технологічних якостей за різних досліджуваних чинників. Встановлено, щзо за проведення оранки на глибину 30-32 см під иукрові буряки і плоскорізного розпушення на глибину 20-22 см під зернові культури на фоні внесення під буряки $25 \mathrm{~m} / 2$ га гною $+N_{90} P_{120} K_{90}$ + солома одержано найбільшу продуктивність иукрових буряків: урожайність коренеплодів та збір иукру становили 52,7 m/2а та 9,28 m/2а відповідно.

Ключові слова: обробіток трунту, сівозміна, иукрові буряки, система удобрення, коренеплоди, иукристість, збір иукру.

Постановка проблеми. Науково обгрунтоване чергування культур у сівозміні разом із правильною системою удобрення i біологічно орієнтованим на культурні рослини обробітком грунту $є$ найважливішими складовими технологій вирощування сільськогосподарських культур, у тому числі й цукрових буряків [5].

Загальновідомо, що саме правильно підібраний і якісно виконаний обробіток грунту сприяє не тільки окультуренню посівних площ сільськогосподарських культур, але й поліпшує їх водно-повітряний, тепловий і поживний режими. За допомогою нього регулюють агрофізичні, біологічні та агрохімічні процеси, що відбуваються в грунті, інтенсивність розкладання і нагромадження органічної речовини, грунтової вологи у кореневмісному шарі й ефективне використання внесених добрив. До того ж обробіток грунту - один із найефективніших агротехнічних заходів боротьби з бур'янами, шкідниками і хворобами цукрових буряків [13].
Щодо збалансованого живлення рослин буряків макро- та мікроелементами, то його роль у системі удобрення набуває першочергового значення. Добре організувавши цей компонент технології їх вирощування, можна поліпшити здатність культури опиратися негативному впливу чинників зовнішнього середовища та патогенних мікроорганізмів i, як наслідок, - зекономити кошти на захисті рослин цукрових буряків.

Отже, обробіток грунту, як і науково обгрунтоване чергування культур та система їх удобрення, були і залишаються невід'ємною і важливою складовою технологій вирощування всіх сільськогосподарських культур, у тому числі й цукрових буряків, у різні часи розвитку сільського господарства.

Деякі науковці вважають, що ні систематична мілка оранка, ні плоскорізний обробіток за впливом на врожайність культур зернобурякової сівозміни не мають переваги перед різноглибинною оранкою. За їх безперервного застосування врожайність сільськогосподарських культур поступово зменшується, особливо без внесення добрив. Також вони стверджують, що продуктивність культур не знижується, якщо в сівозмінах застосовують комбінований обробіток грунту, що включає глибоку оранку під цукрові буряки і мілкий обробіток (дисковий або плоскорізний) під зернові та кормові культури [3].

Інші науковці щодо цього мають протилежну думку. Все це засвідчує актуальність досліджень впливу різних способів обробітку грунту й удобрення на продуктивність цукрових буряків, особливо в зоні недостатнього зволоження, стосовно якої відповідних дослідних даних украй недостатньо.

Аналіз основних досліджень і публікацій, у яких започатковано розв'язання проблеми. 
Урожайність цукрових буряків залежить від досконалості всіх елементів технології, найважливішими 3 яких $є$ розміщення їх після кращих попередників, оптимальний рівень насиченості буряками сівозміни із врахуванням грунтовокліматичних умов, застосування економічно виправданих норм добрив, екологічних способів обробітку грунту $[2,8,19,20,22]$.

Продуктивність цієї цукровмісної культури, як зазначає О. В. Бойчук (2015), значною мірою залежить від способів обробітку грунту і системи удобрення. У плодозмінній короткоротаційній сівозміні, стверджує науковець, урожайність цукрових буряків на фоні $\mathrm{N}_{90} \mathrm{P}_{90} \mathrm{~K}_{130}$ за використання оранки становила 43,8 т/га, за мілкого та плоскорізного обробітку грунту - 44,0 і 42,9 т/га відповідно; збір цукру досягав 7,0, 6,9 і 7,0 т/га відповідно. За проведення плоскорізного обробітку грунту відмічали істотне зростання цукристості коренеплодів на 0,67 \% порівняно з оранкою. Поєднання мілкої оранки на 12-14 см із розпушенням стійками «Параплау» на 30-32 см сприяло одержанню 49,4 т/га коренеплодів і 7,8 т/га збору цукру. Зменшення глибини обробітку грунту до 4-5 см знизило урожайність коренеплодів і збір цукру до 36,7 і 6,2 т/га відповідно, що пов'язано, як вважає вчений, із погіршенням поживного режиму та агрофізичного стану грунту [5].

Систематичне застосування мілкої оранки та плоскорізного обробітку грунту в сівозмінах із цукровими буряками, за їх високої концентрації, недопустиме, особливо без внесення достатньої кількості органічних і мінеральних добрив. Разом із тим, як показали дослідження Л. А. Барштейна, І. С. Шкаредного і В. М. Якименка (2002), поєднання мілкого дискового та плоскорізного обробітку грунту, що застосовувався під зернові культури, з глибокою оранкою, яку виконували під цукрові буряки, порівняно із різноглибинною оранкою під вищевказані культури, не знижує їх урожайності [3].

Систематичне виконання мілкого або безвідвального обробітку грунту, продовжують науковці, недоцільне. Навіть після внесення достатньої кількості добрив та засобів захисту врожаю від хвороб, шкідників та бур'янів, згодом воно призводить до зниження врожаю культур сівозміни, особливо цукрових буряків [13].

Важливим фактором підвищення урожайності цукрових буряків є застосування добрив [7, 10, $11,14]$. Найвищий приріст урожайності цукрових буряків досягається за внесення повного мінерального добрива $[15,16,17]$. Найбільші врожаї коренеплодів цукрових буряків, покращання якості їх коренеплодів мають місце за спільного внесення органічних і мінеральних добрив [18, 23].

За впливом на продуктивність цукрових буряків, як вважають А. С. Заришняк, С. І. Руцька та T. В. Колібабчук (2002), найефективнішими $є$ органічна та мінеральна система удобрення, а також мінеральна у поєднанні з елементами біологічного землеробства [9].

В умовах достатнього зволоження кращою системою удобрення, як зазначив Г. М. Мазур (2007), $є \mathrm{~N}_{90} \mathrm{P}_{110} \mathrm{~K}_{130}+40$ т/га гною, що дає можливість отримувати високі та стабільні урожаї цукрових буряків [11].

Щодо зони недостатнього зволоження, то тут, як зауважують М. О. Пастух, В.В.Герасименко і Н. А. Мостьовна (2008), потрійна норма NPK $\left(\mathrm{N}_{135} \mathrm{P}_{180} \mathrm{~K}_{135}\right) 3$ органічними добривами сприяла збільшенню врожаю цукрових буряків на 13,5 т/га [14].

Отже, проведення раціонального обробітку грунту та застосування оптимального удобрення сприяє підвищенню продуктивності цукрових буряків. Проте дослідних даних щодо зони недостатнього зволоження про вплив способів обробітку грунту й удобрення на продуктивність цукрових буряків украй недостатньо.

Мета досліджень - встановлення впливу способів основного обробітку грунту на продуктивність цукрових буряків за органічної та мінеральної систем їх удобрення в короткоротаційній плодозмінній сівозміні; уточнення біологічних особливостей формування врожаю коренеплодів та їх технологічних якостей.

Завдання досліджень:

1. Дослідити вплив способів основного обробітку грунту і системи удобрення на врожайність цукрових буряків.

2. Вивчити дію відповідних систем обробітку грунту та добрив на технологічні якості коренеплодів цукровмісної культури.

3. Дослідити і проаналізувати особливості росту і розвитку рослин цукрових буряків за різних способів основного обробітку грунту в сівозміні та за різних систем удобрення.

Матеріали і методи досліджень. Польові дослідження проводили у стаціонарному досліді Веселоподільської дослідно-селекційної станції Інституту біоенергетичних культур і цукрових буряків Національної академії аграрних наук України (Семенівський район, Полтавська область) упродовж 2013-2015 рр. У результаті досліджень передбачалось встановити в короткоротаційній плодозмінній сівозміні вплив способів основного обробітку грунту на продуктивність цукрових буряків залежно від фонів їх удобрення. 


\section{СІЛЬСЬКЕ ГОСПОДАРСТВО. РОСЛИННИЦТВО}

Грунт дослідного поля - чорнозем типовий слабкосолонцюватий малогумусний середньосуглинковий, що характеризується такими агрохімічними показниками орного шару: $\mathrm{pH}$ сольової витяжки 7,2-7,7; ємність поглинання коливається в межах 37-39 мг-екв. на 100 г грунту; гумус за Тюріним 4,5-4,7\%, забезпеченість рухомим фосфором та обмінним калієм (за Мачигіним) становить 50,964,5 і 143,2-153,2 мг/кг грунту відповідно.

Територія станції знаходиться в зоні недостатнього зволоження Лівобережного Лісостепу, де середня багаторічна кількість опадів за даними метеостанції Веселий Поділ протягом року становить 511 мм, за вегетаційний період - 326 мм. Клімат - помірно-континентальний з недостатнім зволоженням. Середньобагаторічна середньорічна температура повітря становить $+7,7{ }^{\circ} \mathrm{C}$, сума активних температур $(>+50 \mathrm{C})-2030{ }^{\circ} \mathrm{C}$, сума ефективних температур $(>+100 \mathrm{C})-1275^{\circ} \mathrm{C}$.

Агрометеорологічні умови за роки проведення досліджень охарактеризувались деякими відхиленнями від середніх багаторічних показників, але в цілому вони були сприятливими для вирощування цукрових буряків та інших сільськогосподарських культур.

У короткоротаційній плодозмінній сівозміні 3 різними способами основного обробітку грунту під цукрові буряки, залежно від фонів їх удобрення, чергування культур було наступним: багаторічні трави (еспарцет + костриця лучна), озима пшениця, цукрові буряки, ячмінь 3 підсівом багаторічних трав.

Схема стаціонарного досліду включала такі способи основного обробітку грунту під цукрові буряки і зернові культури: контроль - оранка на глибину 30-32 см під цукрові буряки, оранка на глибину 20-22 см під зернові культури (варіанти $9,10,11,12)$; комбінований обробіток грунту оранка на глибину 30-32 см під цукрові буряки, плоскоріз на глибину 20-22 см під зернові культури (варіанти 15, 16, 17, 18).

У досліді було передбачено наступну систему удобрення цукрових буряків: без добрив і без соломи (варіанти 9, 15); 25 т/га гною $+\mathrm{N}_{90} \mathrm{P}_{120} \mathrm{~K}_{90}$ без соломи (варіанти 10, 16); 25 т/га гною + $\mathrm{N}_{90} \mathrm{P}_{120} \mathrm{~K}_{90}+$ солома (варіанти 11,17 ); $\mathrm{N}_{140} \mathrm{P}_{120} \mathrm{~K}_{90}$ + солома (варіанти 12, 18). Сівозміна стаціонарного досліду розміщена на чотирьох полях; загальна площа посівної ділянки -182 м², облікової

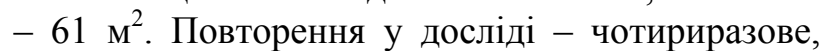
розміщення ділянок - систематичне.

Технологія вирощування сільськогосподарських культур у досліді - загальноприйнята для зони недостатнього зволоження. Оранку під цукрові буря- ки і зернові культури проводили плугом ПН-3-35; плоскорізне безполицеве розпушування під зернові культури виконували стійками «Параплау».

На дослідних ділянках використовували насіння районованих сортів та гібридів відповідних культур: гібрид цукрових буряків - Булава, сорт озимої пшениці - Ссенія, сорт ячменю - Геліос, сорт еспарцету - Піщаний 1251, сорт костриці лучної - Веселоподолянська 1883.

Аналіз вмісту цукру в коренеплодах цукрових буряків проводили на автоматизованій лінії «Венема»; облік урожайності цукрових буряків здійснювали поділянково-суцільним зважуванням.

Дослідження проводили відповідно до методики польового досліду [6] і виконували згідно 3 методичними вказівками ІБКіЦБ [12].

Результати досліджень. Проведені нами трирічні дослідження показали, що в короткоротаційній плодозмінній сівозміні продуктивність цукрових буряків залежала від способів основного обробітку грунту і системи удобрення.

За проведення оранки на глибину 30-32 см під цукрові буряки і 20-22 см під зернові культури на фоні без добрив, без соломи (варіант 9) одержано найнижчу за роки досліду серед варіантів відповідної системи обробітку грунту врожайність цукрових буряків - 37,3 т/га (див. табл.).

Проведення оранки на глибину 30-32 см під цукрові буряки і 20-22 см під зернові культури на фоні внесення під буряки $\mathrm{N}_{140} \mathrm{P}_{120} \mathrm{~K}_{90}$ i соломи (варіант 12) сприяло підвищенню їх урожайності до рівня 48,4 т/га. Оранка на глибину 30-32 см під цукрові буряки i на 20-22 см під зернові культури, як на фоні застосування під буряки 25 т/га гною $+\mathrm{N}_{90} \mathrm{P}_{120} \mathrm{~K}_{90}$ без соломи (варіант 10), так і на фоні застосування під них 25 т/га гною + $\mathrm{N}_{90} \mathrm{P}_{120} \mathrm{~K}_{90}$ і соломи (варіант 11), забезпечила за роки досліджень однакову урожайність буряків по 50,8 т/га. Це, на нашу думку, обумовлено високим рівнем забезпечення грунту рухомим фосфором і обмінним калієм за спільного застосування органічних та мінеральних добрив.

За проведення оранки на глибину 30-32 см під цукрові буряки і плоскорізного розпушення на 20-22 см під зернові культури (комбінований обробіток грунту) на фоні без добрив і без соломи (варіант 15), отримали найменшу за роки досліду врожайність буряків - 36,0 т/га. Проте такий обробіток грунту, але вже на удобрених фонах, спричинив зростання врожайності коренеплодів цукрових буряків: за внесення під буряки 25 т/га гною $+\mathrm{N}_{90} \mathrm{P}_{120} \mathrm{~K}_{90}$ без соломи (варіант 16) - до 49,0 т/га, за внесення під буряки $\mathrm{N}_{140} \mathrm{P}_{120} \mathrm{~K}_{90}$ + солома (варіант 18) - до 51,0 т/га. 
Продуктивність цукрових буряків у короткоротаційній плодозмінній сівозміні залежно від способів основного обробітку трунту і системи удобрення (в середньому за 2013-2015 рр.)

\begin{tabular}{|c|c|c|c|c|c|}
\hline \multirow{2}{*}{$\begin{array}{l}\text { Ba- } \\
\text { pi- } \\
\text { aнт }\end{array}$} & \multirow[b]{2}{*}{$\begin{array}{c}\text { Спосіб основного обробітку грунту під } \\
\text { цукрові буряки і зернові культури }\end{array}$} & \multirow{2}{*}{$\begin{array}{l}\text { Система } \\
\text { удобрення } \\
\text { цукрових } \\
\text { буряків }\end{array}$} & \multicolumn{3}{|c|}{$\begin{array}{c}\text { Продуктивність цукрових } \\
\text { буряків }\end{array}$} \\
\hline & & & $\begin{array}{l}\text { урожай- } \\
\text { ність, т/га }\end{array}$ & $\begin{array}{l}\text { цукрис- } \\
\text { тість, \% }\end{array}$ & $\begin{array}{l}\text { збір } \\
\text { цукру, } \\
\text { т/га }\end{array}$ \\
\hline 9 & $\begin{array}{l}\text { Оранка на глибину 30-32 см під цукрові } \\
\text { буряки і 20-22 см під зернові культури } \\
\text { (контроль) }\end{array}$ & $\begin{array}{l}\text { Без добрив, } \\
\text { без соломи }\end{array}$ & 37,3 & 16,9 & 6,30 \\
\hline 10 & $\begin{array}{l}\text { Оранка на глибину 30-32 см під цукрові } \\
\text { буряки і 20-22 см під зернові культури } \\
\text { (контроль) }\end{array}$ & $\begin{array}{c}25 \text { т/га гною }+ \\
+\mathrm{N}_{90} \mathrm{P}_{120} \mathrm{~K}_{90} \\
\text { без соломи }\end{array}$ & 50,8 & 17,6 & 8,94 \\
\hline 11 & $\begin{array}{l}\text { Оранка на глибину 30-32 см під цукрові } \\
\text { буряки і 20-22 см під зернові культури } \\
\text { (контроль) }\end{array}$ & $\begin{array}{l}25 \text { т/га гною + } \\
+\mathrm{N}_{90} \mathrm{P}_{120} \mathrm{~K}_{90}+ \\
+ \text { солома } \\
\end{array}$ & 50,8 & 17,0 & 8,64 \\
\hline 12 & $\begin{array}{l}\text { Оранка на глибину 30-32 см під цукрові } \\
\text { буряки і 20-22 см під зернові культури } \\
\text { (контроль) }\end{array}$ & $\begin{array}{c}\mathrm{N}_{140} \mathrm{P}_{120} \mathrm{~K}_{90}+ \\
\text { солома }\end{array}$ & 48,4 & 16,5 & 7,99 \\
\hline 15 & $\begin{array}{l}\text { Оранка на глибину 30-32 см під цукрові } \\
\text { буряки, плоскоріз на 20-22 см під зерно- } \\
\text { ві культури (комбінований обробіток } \\
\text { грунту) }\end{array}$ & $\begin{array}{l}\text { Без добрив, } \\
\text { без соломи }\end{array}$ & 36,0 & 16,5 & 5,94 \\
\hline 16 & $\begin{array}{l}\text { Оранка на глибину } 30-32 \text { см під цукрові } \\
\text { буряки, плоскоріз на 20-22 см під зерно- } \\
\text { ві культури (комбінований обробіток } \\
\text { грунту) }\end{array}$ & $\begin{array}{l}25 \text { т/га гною + } \\
+\mathrm{N}_{90} \mathrm{P}_{120} \mathrm{~K}_{90} \\
\text { без соломи }\end{array}$ & 49,0 & 17,8 & 8,72 \\
\hline 17 & $\begin{array}{l}\text { Оранка на глибину 30-32 см під цукрові } \\
\text { буряки, плоскоріз на 20-22 см під зерно- } \\
\text { ві культури (комбінований обробіток } \\
\text { грунту) }\end{array}$ & $\begin{array}{c}25 \text { т/га гною }+ \\
\mathrm{N}_{90} \mathrm{P}_{120} \mathrm{~K}_{90}+ \\
\text { солома }\end{array}$ & 52,7 & 17,6 & 9,28 \\
\hline 18 & $\begin{array}{l}\text { Оранка на глибину } 30-32 \text { см під цукрові } \\
\text { буряки, плоскоріз на 20-22 см під зерно- } \\
\text { ві культури (комбінований обробіток } \\
\text { грунту) }\end{array}$ & $\begin{array}{c}\mathrm{N}_{140} \mathrm{P}_{120} \mathrm{~K}_{90}+ \\
\text { солома }\end{array}$ & 51,0 & 17,0 & 8,67 \\
\hline \multicolumn{3}{|c|}{ HIP $_{05}$ загальна } & 1,5 & 0,5 & 0,32 \\
\hline \multicolumn{3}{|c|}{ HIP $_{05}$ для ф-ра А (обробіток грунту) } & 1,0 & 0,4 & 0,23 \\
\hline \multicolumn{3}{|c|}{ HIP $_{05}$ для ф-ра В (удобрення) } & 0,8 & 0,3 & 0,17 \\
\hline
\end{tabular}

Проведення в сівозміні оранки на глибину 3032 см під цукрові буряки і плоскорізного розпушення грунту на 20-22 см під зернові культури на фоні застосування під буряки 25 т/га гною + $\mathrm{N}_{90} \mathrm{P}_{120} \mathrm{~K}_{90}+$ солома (варіант 17) сприяло отриманню найвищої за роки досліджень урожайності коренеплодів серед усіх варіантів - 52,7 т/га.

Отже, максимальна середня врожайність коренеплодів цукрових буряків за три роки досліджень $(52,7 \mathrm{~T} /$ га) була отримана із ділянок, де проводили саме оранку на глибину 30-32 см під цукрові буряки і плоскорізне розпушення грунту на 20-22 см під зернові культури на фоні внесення під цукровмісну культуру 25 т/га гною + $\mathrm{N}_{90} \mathrm{P}_{120} \mathrm{~K}_{90}$ і соломи. Мінімальною врожайність буряків виявилася на ділянках, де під них і під зернові культури проводили оранку на глибину 30-32 см і 20-22 см відповідно на фоні без добрив, без соломи та на ділянках, де проводили оранку на глибину 30-32 см під цукрові буряки i плоскорізне розпушення грунту на 20-22 см під зернові культури на фоні без добрив і без соломи, - 37,3 і 36,0 т/га відповідно.

Окрім урожайності, важливим показником для цукрових буряків, на який впливають обробіток грунту і дози добрив, є цукристість їх коренеплодів [1, 4, 21].

Результати наших трирічних досліджень показали, що за проведення оранки на глибину 30-32 см під цукрові буряки і на 20-22 см під зернові 


\section{СІЛЬСЬКЕ ГОСПОДАРСТВО. РОСЛИННИЦТВО}

культури на фоні внесення під буряки $\mathrm{N}_{140} \mathrm{P}_{120} \mathrm{~K}_{90}$ і соломи (варіант 12) цукристість коренеплодів буряків становила 16,5 \% і виявилася меншою на $0,5 \%$ порівняно із варіантом 11 , де проводили оранку на глибину 30-32 см під цукрові буряки i 20-22 см під зернові культури на фоні внесення під буряки 25 т/га гною $+\mathrm{N}_{90} \mathrm{P}_{120} \mathrm{~K}_{90}+$ солома, що обумовлено підвищеним рівнем азоту (табл. 1). За проведення оранки на глибину 30-32 см під цукрові буряки і 20-22 см під зернові культури на фоні застосування під буряки 25 т/га гною + $\mathrm{N}_{90} \mathrm{P}_{120} \mathrm{~K}_{90}$ без соломи (варіант 10) отримали коренеплоди із найвищим вмістом цукру (17,6 \%) серед варіантів відповідної системи обробітку грунту.

Проведення оранки на глибину 30-32 см під цукрові буряки i плоскорізного розпушення грунту на 20-22 см під зернові культури (комбінований обробіток грунту), за внесення під буряки 25 т/га гною $+\mathrm{N}_{90} \mathrm{P}_{120} \mathrm{~K}_{90}$ без соломи (варіант 16), так і за внесення під них 25 т/га гною $+\mathrm{N}_{90} \mathrm{P}_{120} \mathrm{~K}_{90}+$ солома (варіант 17), забезпечило найвищу за три роки цукристість коренеплодів за такої системи обробітку грунту - 17,8 і 17,6 \% відповідно.

Отже, система обробітку грунту, що включає проведення оранки на глибину 30-32 см під цукрові буряки і 20-22 см під зернові культури на фоні застосування під буряки 25 т/га гною + $\mathrm{N}_{90} \mathrm{P}_{120} \mathrm{~K}_{90}$ без соломи забезпечила найвищу серед контрольних за обробітком грунту варіантах цукристість коренеплодів на рівні 17,6 \%. Комбінований же обробіток грунту на фонах внесення під цукрові буряки 25 т/га гною $+\mathrm{N}_{90} \mathrm{P}_{120} \mathrm{~K}_{90}$ без соломи і $25 \mathrm{~T} /$ га гною $+\mathrm{N}_{90} \mathrm{P}_{120} \mathrm{~K}_{90}+$ солома посприяв формуванню найвищої серед такої системи обробітку грунту цукристості коренеплодів буряків - 17,8 і 17,6 \% відповідно.

Збір цукру, що вважається головним показни-

\section{БІБЛІОГРАФІЯ}

1. Аркуша В. Ю. Особливості удобрення цукрових буряків на чорноземах реградованих правобережного Лісостепу України / В. Ю. Аркуша, А. I. Буджерак // Система землеробства у буряківництві. - К. : Аграрна наука, 1997. - С. 140-144.

2. Баритейн Л. А. Основа технології вирощування цукрових буряків / Л. А. Барштейн // Система землеробства у буряківництві. - К. : Аграрна наука, 1997. - С. 3-5.

3. Баритейн Л. А. Сівозміни, обробіток грунту та удобрення в зонах бурякосіяння / Л. А. Барштейн, І. С. Шкаредний, В. М. Якименко. - К. : Тенар, 2002. - 488 с.

4. Бедринець B. K. Вплив систем удобрення i захисту рослин на продуктивність та екологічну ком бурякоцукрового виробництва, також залежав за роки досліджень від способів основного обробітку грунту під культури в сівозміні і системи удобрення цукрових буряків. Так, наприклад, проведення оранки на глибину 30-32 см під цукрові буряки i на 20-22 см під зернові культури на фоні без добрив, без соломи (варіант 9) та проведення оранки на глибину 30-32 см під цукрові буряки і плоскорізного розпушення грунту на 20-22 см під зернові культури на фоні без добрив, без соломи (варіант 15) спричинило одержання найнижчого збору цукру - 6,30 і 5,94 т/га відповідно (див. табл.). За проведення оранки на глибину 30-32 см під цукрові буряки і на 20-22 см під зернові культури, як на фоні застосування під буряки 25 т/га гною $+\mathrm{N}_{90} \mathrm{P}_{120} \mathrm{~K}_{90}$ без соломи (варіант 10), так і на фоні застосування під них 25 т/га гною $+\mathrm{N}_{90} \mathrm{P}_{120} \mathrm{~K}_{90}+$ солома (варіант 11), одержано майже однаковий збір цукру - 8,94 i 8,64 т/га відповідно. Проведення оранки на глибину 30-32 см під цукрові буряки і плоскорізного розпушення грунту на 20-22 см під зернові культури на фоні внесення під буряки 25 т/га гною $+\mathrm{N}_{90} \mathrm{P}_{120} \mathrm{~K}_{90}+$ солома (варіант 17) забезпечило найбільший за роки досліду збір цукру 9,28 т/га.

Висновок. У короткоротаційній плодозмінній сівозміні продуктивність цукрових буряків залежить від способів обробітку грунту під культури сівозміни і системи удобрення буряків. Максимальними показники продуктивності цукрових буряків одержані на варіанті, де проводили під них оранку на глибину 30-32 см і плоскорізне розпушення грунту на глибину 20-22 см під зернові культури на фоні внесення під буряки 25 т/га гною $+\mathrm{N}_{90} \mathrm{P}_{120} \mathrm{~K}_{90}+$ солома: урожайність коренеплодів та збір цукру тут становили 52,7 т/га та 9,28 т/га відповідно.

чистоту цукрових буряків / В.К. Бедринець, A. I. Буджерак // Система землеробства у буряківництві. - К. : Аграрна наука, 1997. - С. 145-148.

5. Бойчук О. В. Вплив обробітку грунту на його родючість та продуктивність короткоротаційної плодозмінної сівозміни Правобережного Лісостепу України : автореф. дис. на здобуття наук. ступеня к. с.-г. н. : спец. 06.01.01 «Загальне землеробство» / О. В. Бойчук. - К., 2015. - 23 с.

6. Доспехов Б. А. Методика полевого опыта с основами статистической обработки результатов исследований : [монография] / Б. А. Доспехов. М. : Колос, 1979. - 416 с.

7. Ефективність добрив і обробітку грунту під цукрові буряки в північному Степу України / [Че- 
рячукін М. І., Григор'єва О. М., Григор'єв М. I., Сушко Т. П.] // Цукрові буряки. - 2001. - №1. C. $12-13$.

8. Заришняк А. С. Вплив форм фосфорних добрив на продуктивність цукрових буряків / А. С. Заришняк, М. М. Якусик // Цукрові буряки. - 2003. - №6. - C. 13-14.

9. Заришняк А. С. Добрива, врожайність та винос елементів живлення / А.С. Заришняк, С. I. Руцька, Т. В. Колібабчук // Цукрові буряки. - 2002. - №1. - C. 6-7.

10. Заришняк A. С. Утилизация отходов животноводства и растениеводства / А. С. Заришняк, А. А. Сыпко // Сахарная свекла. - 2007. №8. - C. 19-20.

11. Мазур Г. М. Вплив систем удобрення на технологічну якість коренеплодів цукрових буряків / Г. М. Мазур // Цукрові буряки. - 2007. №5. - С. 9-11.

12. Методика исследований по сахарной свекле / [Зубенко В. Ф., Борисюк В. А., Балков И. Я. и др.]. - К. : ВНИС, 1986. - 292 с.

13. Основний обробіток грунту - важливий елемент технології вирощування цукрових буряків та інших сільськогосподарських культур / [Барштейн Л. А., Якименко В. М., Шкаредний І. С. та ін.] // Система землеробства у буряківництві. - К. : Аграрна наука, 1997. - С. 57-73.

14. Пастух М. О. Використання продуктивної вологи, добрива і поживний режим грунту / М. О. Пастух, В.В.Герасименко, Н. А. Мостьовна // Цукрові буряки. - 2008. - №3-4. - С. 33-34.
15. Рӧ̈к M. В. Хвороби коренеплодів цукрових буряків / М. В. Роїк, А. К. Нурмухаммедов, А. С. Корнієнко. - К. : Поліграф Консалтинг, 2004. $-224 \mathrm{c}$.

16. Саблук В. Т. Шкідники сходів цукрових буряків / В. Т. Саблук. - К. : Світ, 2002. - 182 с.

17. Сівозміни у землеробстві України / [за ред. В. Ф. Сайка, П. І. Бойка]. - К. : Аграрна наука. 2002. $-148 \mathrm{c}$.

18. Сушков М. Д. В технологии возделывания сахарной свеклы важен каждый элемент / М. Д. Сушков // Сахарная свекла. - 2007. - №10. - С. 13-16.

19. Цвей Я. П. Наукові принципи перебудови сівозмін / Я. П. Цвей // Цукрові буряки. - 2005. №1. - C. 7-9.

20. Цвей Я. П. Продуктивність короткоротаційних сівозмін в Лісостепу України / Я. П. Цвей, А. М. Горобець // Цукрові буряки. 2006. - №6. - C. 10-11.

21. Шиманська Н. К. Вплив біологічного азоту на продуктивність культур сівозміни / Н. К. Шиманська // Система землеробства у буряківництві. - К. : Аграрна наука, 1997. - С. 125-140.

22. Эффективность интенсивной технологии выращивания сахарной свеклы / [Пыркин В. И., Кисель О. А., Гизбуллина Л. Н. и др.] // Сахарная свекла. - 2006. - №5. - С. 8-11.

23. Эффективность последействия удобрений / [Ступаков А. Г., Чернышова А. П., Куликова М. А., Зиятдинов Д. А.] // Сахарная свекла. 2007. - №4. - С. 19-21. 